\title{
RHEUMATOID ARTHRITIS AND PLASMACYTOMATOSIS
}

\author{
BY \\ TOMASO 'GALLI AND ENRICO' CHITI \\ From the Rheumatology Department of the Institute of Clinical Medicine, University of Genoa \\ (Director: Prof. Lorenzo Antognetti) \\ (RECEIVED FOR PUBLICATION NOVEMBER 17, 1954)
}

The importance of plasma disorders in the diagnosis and pathogenesis of rheumatoid arthritis is well known. Galli and others $(1949 a, b, c)$ have studied the erythrocyte sedimentation rate, the occurrence of amyloidosis, and the alteration of the protein composition of plasma, and examined the inter-relations of plasma disorders with the signs and symptoms of rheumatoid arthritis.

It was concluded that an increase in the erythrocyte sedimentation rate was a sign not only of an inflammatory state involving the joints, but also of a pathological systemic condition. The correlation of the erythrocyte sedimentation rate with plasma protein production suggested that alterations in the latter were phenomena of the disease process.

The amyloidosis studies led to the assumption that a fault in the mesenchyma might cause changes in blood and tissue protein metabolism.

Blood-protein disorders were shown to play a part in the pathogenesis of rheumatoid arthritis which was linked with the state of the plasma proteins.

Chini (1955) has discussed a new type of joint pathology, which he calls "dysprotidaemic joint disease". This conception arose from the frequency of plasma cell and reticulo-endothelial proliferation in rheumatoid arthritis, the frequent concomitant amyloidosis, and the evidence of joint damage in such blood-protein disorders as myeloma, and primary and secondary amyloidosis. The histiocytic hyperplasia inside and outside the bone marrow, which has been demonstrated in rheumatoid arthritis, suggests that a systemic histioplasmacytic hyperplasia occurs in this condition.

These data suggest that anomalous protein production takes place at the sites of plasma cell proliferation (Poli, 1948, 1949; Redaelli and Gianni, 1949; and Vidari, 1941, 1946).

There is evidence of joint damage in myeloma, with accumulation of amyloid substance in the articular tissues (Delbarre, 1949; Laake, 1949; Magnus-Levy, 1932, 1938; Snapper, 1938; Stadler, 1939; Weissenbach and Faulong, 1948); the main joints are usually involved (Apitz, 1940a, b; Del- barre, 1949); the condition resembles arthrosis (Stadler, 1939), though more joints may be affected, and appears to be similar to rheumatoid arthritis. Delbarre speaks of "amyloid rheumatism" (Apitz, 1940a, b; Stewart and Weber, 1938; Tarr and Ferris, 1939; Weissenbach and Faulong, 1948).

According to Chini (1955), the articular involvement may imply a multiple pathogenic mechanism:

(1) contiguous diffusion of myelomatous bone damage;

(2) amyloid accumulation in articular tissues;

(3) systematized involvement of the histiocytic joint tissues by the myelomatous process, with precipitation of abnormal proteins into the articular tissues;

(4) secondary histogenetic reaction inducing granulomatous and fibrous processes.

Little is known of articular involvement in classical secondary amyloidosis (Cesa-Bianchi and Poli, 1948; Lengh, 1937). Joint lesions are seldom found in systemic primary amyloidosis (Bonsdorff, 1934; Dahlin, 1949; Lengh, 1937; Lubarsch, 1929; Ronchetti, 1930; Stadler, 1939). Articular manifestations of blood protein disorders, other than myeloma and amyloidosis, are rare, but do arise in generalized dysreactive mesenchymal ("pararheumatic") disorders, in which a plasma cell reaction is the outstanding feature of the proliferative process.

These researches, the observation of a case clinically resembling rheumatoid arthritis but labelled by Chini as "dysprotidaemic joint lesions", and the finding of hyalinosis and paramylosis of the articular tissues, led to the belief that anomalous proteins or abnormal amounts of protein may accumulate in the joints with amyloid or paraamyloid local alterations.

The following case demonstrates the relation of joint disease with blood protein disorder.

\section{Case History}

A married woman, aged 47 , had suffered from arthralgia at intervals since an operation 12 years before.

General History.-Her grandparents died in senility; 
her father was alive and well, but suffered from sciatica; her mother, who died aged 62, had suffered from "joint disease". She was born at full-term, had regular onset of menarche, but slightly excessive and painful, was married at age 20 to a healthy man, and had had one healthy child, and no abortions.

At 34, after a partial surgical removal of ovary and uterus, the menses became scanty and delayed, and later (from December, 1952) menstruation had ceased completely. She had always worked as a housewife, lived in healthy surroundings, and had sufficient food.

Medical History.-As a child she suffered from rubella, and at 13 developed diffuse skin folliculitis, which disappeared at the menarche. At 19 she recovered from diphtheria without complications. At 23 she became very thin and suffered from psychoneurosis. Climato-therapy and general stimulants were of value. At 25 , she complained of a pricking pain referred to the 7 th, 8th, and 9th dorsal ribs, which was exacerbated by motion and refractory to ordinary antirheumatic treatment. As no vertebral lesion was seen radiologically, the patient received iodine for "a long period" and complete remission of symptoms occurred.

At 34, she noted that a vaginal discharge appeared and gradually increased; examination revealed uterine fibromyomatosis, and the patient thus underwent subtotal hysterectomy with hemianexiectomy.

Since then she has been suffering, especially during the winter, from arthralgia localized upon one or more joints; the pain disappeared with antirheumatic treatment.

About 18 months ago (at age 45) she had complained of an acute pain extending to the whole spine, especially the thoraco-lumbar tract; the tibiotarsal joints were sore and swollen, and their function impaired. Short febrile periods occurred, and urticaria-like rashes (itching, reddish pomphi) appeared sporadically on the chest and limbs. Meanwhile all the joints gradually became painful with alternate periods of exacerbation and quiescence. The disease was gradually developing into rheumatoid arthritis and when the patient was admitted to our clinic this diagnosis was confirmed.

Laboratory Findings.-Takata Ucko test highly positive $(+++)$. Most colloidal lability tests positive. Sedimentation rate raised (Katz's index ranged between 80 and 100). No pathological data found in urinalysis and leucocyte counts. Blood picture normal.

Therapy.-After discharge from our clinic, the patient was given gold, hormones, vitamins, and liver-protecting drugs with some benefit.

Further Progress.-In November, 1953, she complained of an exacerbation of articular pains, with high intermittent fever, sharp and insistent cough, little sputum, dyspnoea, cyanosis, and low blood pressure; bluish patches (cutis marmorata), scattered on the whole surface of the limbs and chest, were intensified by the standing position and cold.

The patient was again admitted to the clinic on January 7, 1954.

Examination.-She was pale, thin, and anaemiclooking. Several bluish patches of vascular origin were

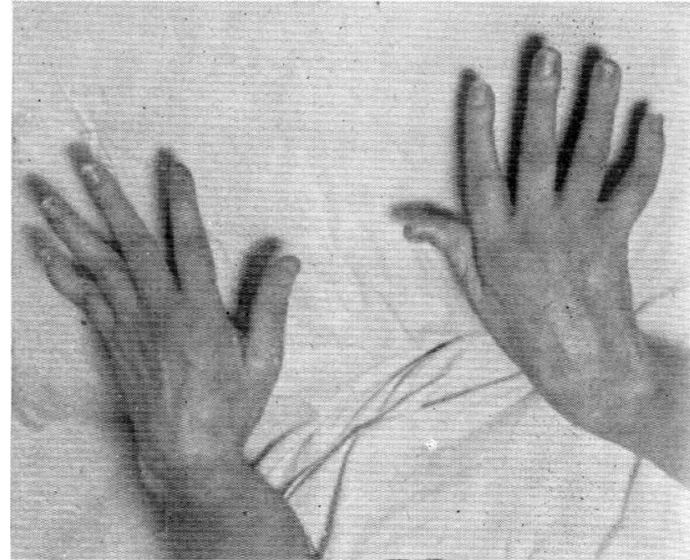

Fig. 1.-Patient's hands, showing distortion and swelling.

scattered on the skin of the limbs. The hands (Fig. 1) and the feet showed evident deformities and wellmarked valgism. Articular motion was generally impaired. The nails were grooved and striped and bore signs of onychotrophy.

The chest expansion was slight, tactile fremitus and percussion resonance were impaired over both lung bases, the right base was raised and scarcely mobile, and the percussion note resonant through the rest of the field; diffuse rhonchi and moist rales were heard over both lungs, with coarse breathing and crepitant rales at the right base.

The cardiovascular system was normal. Bloo $\bar{P}$ pressure 120/90.

The tongue was dry, with reddened margins and central patches due to iodiomycosis, and the mouth and throat were red and covered with white patches.

The upper limits of the liver were slightly higher than normal, the lower edge being smooth, firm, and tender a hand's breadth below the costal margin. The spleen was soft and its inferior pole hardly felt during deep breathing.

Ankylosis and subluxation of the minor joints was present in both hands and feet. Slight tenderness and limitation of movement affected the remaining joints.

\section{Laboratory Findings.}

Urine: Specific gravity 1,010 to 1,015 ; acid reaction; albumin positive $(+)$; sediment: few red blood cells, large number of leucocytes and epithelia; Bence-Jones protein revealed by subsequent analyses.

Blood: Haemoglobin 50 per cent., R.B.C. 3,400,000; haemoglobin index $0 \cdot 70$; W.B.C. 12,000.

Neutrophil leucocytes 73 per cent., eosinophil leucocytes 1 per cent., lymphocytes 25 per cent., monocytes 1 per cent. mild aniso-poikilocytosis; platelets normal in shape and agglutination (ranging from 170,000 to $230,000 / \mathrm{c}$. mm.).

Further blood examinations still showed a more or less marked anaemia due to treatment, and corresponding variations of the W.B.C. and differential counts. In spite of many careful and repeated observations only a few plasma-cells, or more often some Turk's cells and hyperbasophilic cells, were found. 


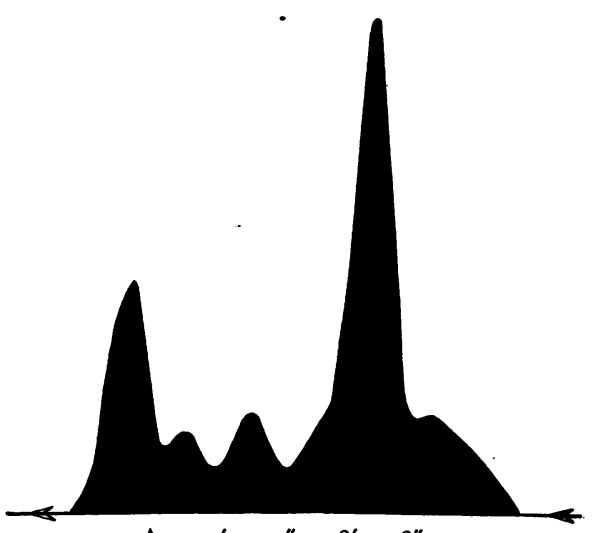

A $\quad \alpha^{\prime} \quad \alpha^{\prime \prime} \quad \beta^{\prime} \quad \beta^{\prime \prime} \quad \gamma$

(a)

Fig. 2.-Electrophoresis (a) paper method;

(b) Tiselius' method.

Erythrocyte Sedimentation Rate: First hour = $146 \mathrm{~mm}$., second hour $=150 \mathrm{~mm}$; the first hour's value may be considered as Katz's index. Subsequent controls always confirmed a very high erythrocyte sedimentation rate with little variation, following the course of the disease and treatment. A greater reduction was obtained after ACTH administration.

Total Plasma Protein: From 7 to 8.5 g. per cent.

Takata Ucko Reactions: Strongly positive $(++++)$; other tests based on plasma protein changes repeatedly positive. per cent.

Paper Electrophoresis (Fig. 2a): Total proteins $8 \cdot 5 \mathrm{~g}$.

Bone Marrow Examination (Fig. 3): Moderate cellularity, with some granuloblastic hyperplasia; marked plasmacytosis ( 0 to 10 per cent.) with morphological signs of "stimulation"; slight eosinophilia. L.E. phenomenon (incubation technique) absent.

A second sternal biopsy performed a month later furnished an abundant pinkish-grey material. At low magnification the smears appeared particularly hypercellular; at higher magnification the plasma cellular stem was the most prominent feature, as shown by the differential count (March 23, 1954):

Haemocytoblasts 0.2 per cent.; Myeloblasts 0.8 per cent.; Promyelocytes, neutrophil 0.4 per cent. Myelocytes, neutrophil 2 per cent., eosinophil 0.4 per cent.; Metamyelocytes, neutrophil 3.4 per cent.; Band granulocytes, neutrophil 1.2 per cent. Erythroblasts, basophils 0.04 per cent., polychromatophils 0.4 per cent., orthochromatophils 2 per matophils 0.4 per cent., orthochromatophils 2 per
cent.; Plasma cells 89 per cent.; Megakaryocytes cent.; Plasma cells 89 per cent.;
0.4 per cent.; Mitoses 0.4 per cent.

These figures show the striking rate of plasmacytosis; a systematic constant study of mitoses showed some unimportant abnormalities; no remarkable obstacle to maturation was noted.

A third bone-marrow puncture confirmed the previous data, though a slight decrease of plasmacytosis was observed. This bone-marrow count was obtained on March 30, 1954, after a course of phenylbutazone.

Haemocytoblasts 1.2 per cent.; Myeloblasts 1.4 per cent.; Promyelocytes, neutrophils $2 \cdot 2$ per cent.; Myelocytes, neutrophils 6.0 per cent., eosinophils 0.6 per cent.; Metamyelocytes phis 6.0 per cent., eosinophils 0.6 per cent.; Metamyelocytes, granulocytes, neutrophils 13.0 per cent.; Proerythroblasts 0.2 per cent.; Erythroblasts, basophils $2 \cdot 4$ per cent., polychromatophils 4.0 per cent., orthochromatophils 4.0 per cent.; Plasma cells 47.6 per cent.; Endothelial cells 1.2 per cent.; Megakaryocytes 0.2 per cent.; Mitoses 0.4 per cent.

Coagulation Test: Tourniquet, hammer, and pinch

Albumin 1.7 g. per cent.; globulin $6 \cdot 8 \mathrm{~g}$. per cent. (ratio 0.25 ); globulin $0.41 \mathrm{~g}$. per cent.; $\alpha 0.75$ g. per cent.; $\beta 0 \cdot 17$ g. percent.; $\beta_{2} 4 \cdot 1$ g. per cent.; $\gamma$ $\beta_{2} 4 \cdot 1$ g. per
$1 \cdot 37 \mathrm{~g}$. per cent.

Electrophoresis (Tiselius) (Fig. 2b): Total proteins $8.5 \mathrm{~g}$. per cent.

Albumin 1.73 g. per cent.; globulin $6 \cdot 77 \mathrm{~g}$. per cent. (A/G ratio $0 \cdot 25) ; \alpha$ globulin 0.71 g. per cent., $\beta 4.97 \mathrm{~g}$.
per cent., $\gamma 1 \cdot 09 \mathrm{~g}$. per cent.

\section{Blood Chemistry:}

Urea Nitrogen: 0.3 per thousand $\mathrm{g}$.; further observations showed a rise to $1 \mathrm{~g}$. per thousand, especially during the later stages:

Chlorine: $3.54 \mathrm{~g}$. per thousand;

Chlorides: $5 \cdot 84 \mathrm{~g}$. per thousand;

Sugar: 1.15 g. per thousand;

Cholesterol: $292 \mathrm{mg}$. per cent., free $52 \mathrm{mg}$. per cent., esterized 240 mg. per cent.

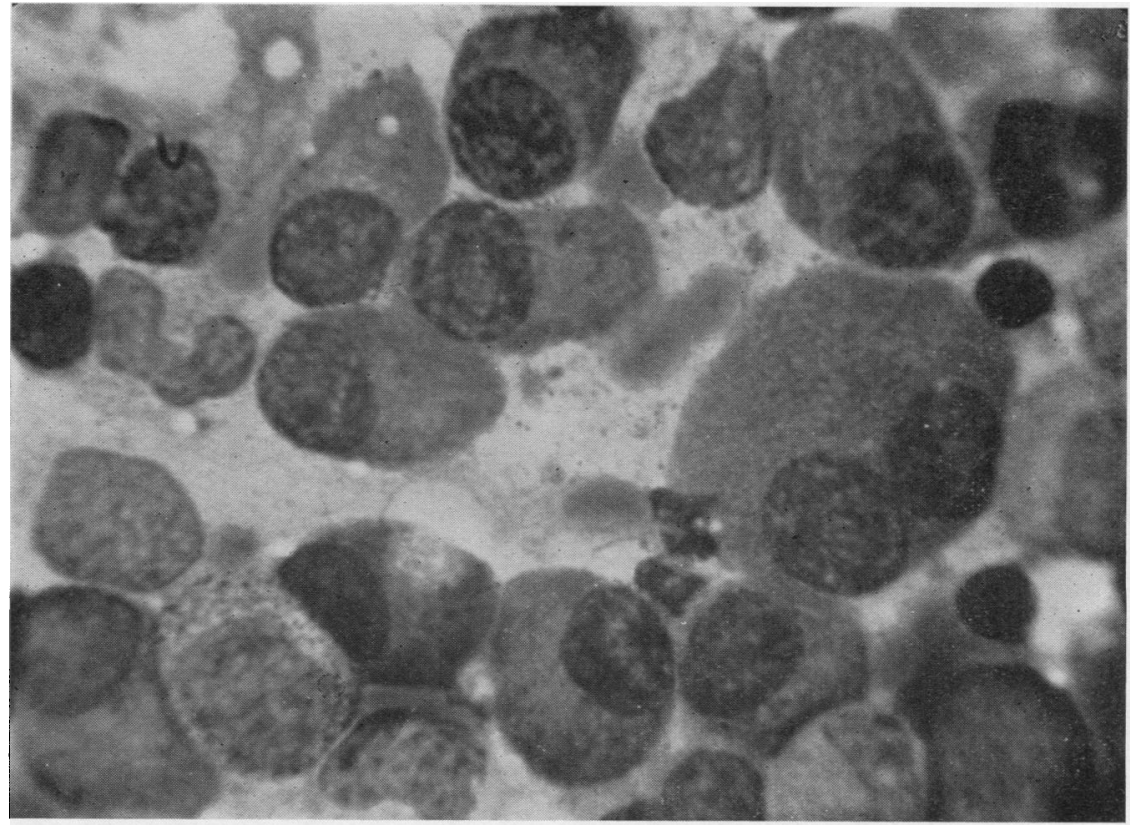

Fig. 3.-Bone-marrow. 


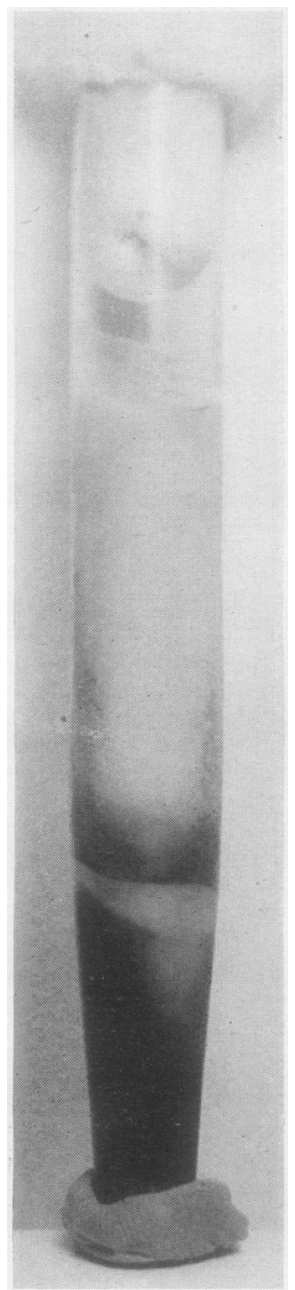

Fig. 4.-Blood coagulation test.

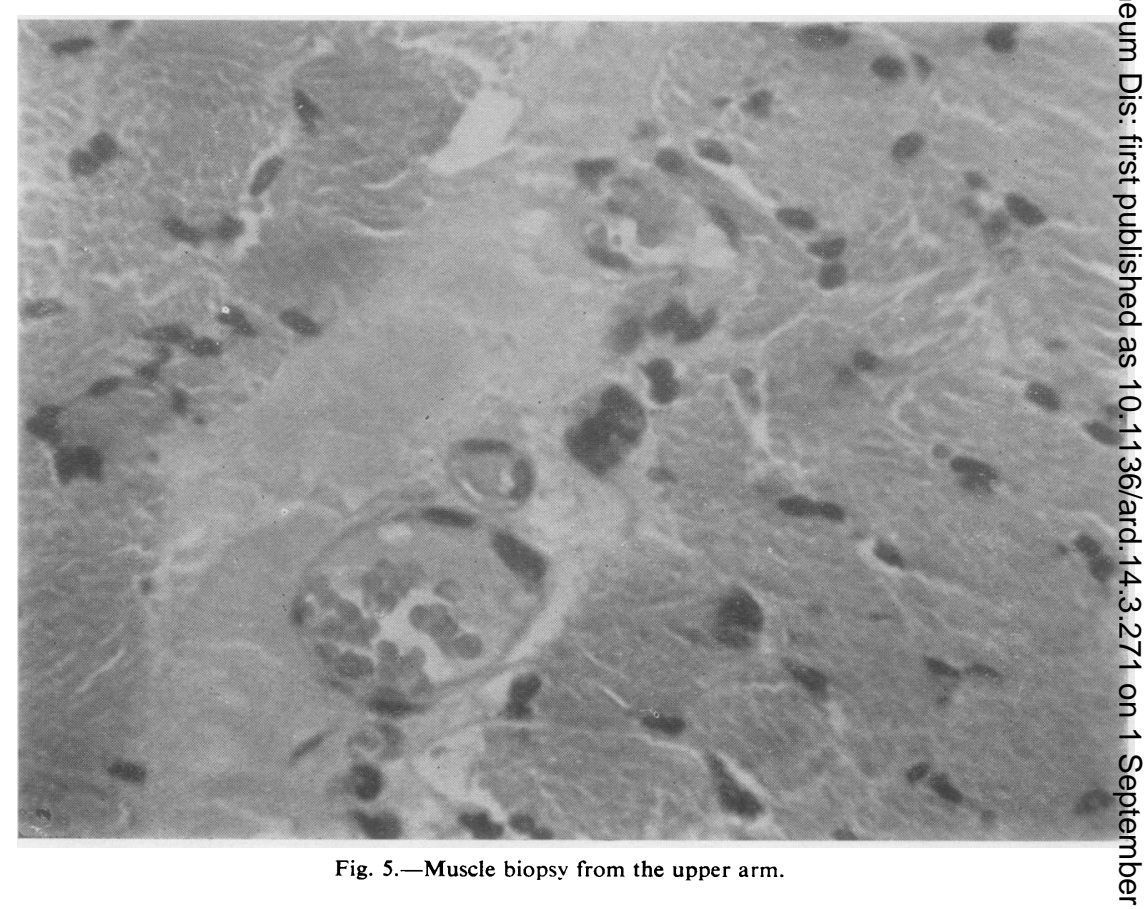

tests, slightly positive; bleeding time moderately delayed ( $4 \frac{1}{2}$ min.); in testing clotting time and clot-retraction time, a prompt and massive coagulation with clouding and whitening of the upper part occurred (Fig. 4).

The amount of serum necessary for examinations could be obtained only by immediate incubation of the blood sample at $37^{\circ} \mathrm{C}$. The serum specimens (fluid when kept at thermostat temperature) appeared much thicker when stored at room temperature in a refrigerator.

Quick's time 20 sec. prothrombin activity 33 per cent. of normal;

Recalcification time $3 \mathrm{~min} .50 \mathrm{sec}$;

Residual prothrombin after 60 min. 21 per cent.;

Accelerating power of serum (prothrombin conversion and S.P. A slow and defective thrombin formation and lack of S.P.C.A.

Blood Culture on several media was negative; Wright and Vidal reactions negative; Wassermann reaction and other tests for syphilis negative; Mycobacterium tuberculosis negative.

Cerebrospinal Fluid (lumbar puncture): Clear as water, containing 3 cells c.mm., albumin $0 \cdot 2 \mathrm{~g}$. per thousand, sugar $0.65 \mathrm{~g}$. per thousand; Wassermann reaction negative; Nonne Appelt negative; Pandy and Weichbrodt reaction showed slight opalescence.

Heart: An electrocardiogram (January 9, 1954) showed only sinus tachycardia with ventricular extrasystole. Another test (January 21, 1954) showed a partial atrioventricular block with nodal escape beats

and bradycardia. By February 12, 1954, the block \&aظ disappeared.

Muscle Biopsy (Fig. 5) from the biceps bractii: Diffuse sclerohyalinosis; lymphocytes and plasma colle infiltrating the interstices and forming dense perivascula muffs around the undamaged arterial walls.

Synovial Biopsy from the knee-joint: Cells wit plasmacellular characteristics (eccentric nuclei, basoథ philic cytoplasma, perinuclear halo) scattered or gathereq between coarse strands of connective tissue, the bloo vessels being surrounded by lymphocyte-like cells Slight infiltration formed by plasmacytomatous elements

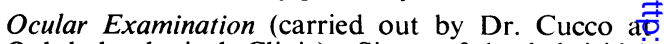
the Ophthalmological Clinic): Signs of healed irido cyclitis were found in both eyes. Slightly opaque patches on the corneae, made ocular examination very difficult.

\section{$X$-ray Examinations}

\section{Skull: Normal.}

Spine: Low grade, leftward scoliosis of superio dorsal segment, with no structural changes, some degree of decalcification and osteoporosis in the ter $\rightarrow$ minal lumbar tract (Fig. 6, opposite). Pseudo-cyst? appearances, due to lacunar porosis, on the edgesof L4 and L5. Posterior arches of sacro-iliag synchondroses showed inter-articular defects.

Legs: Small spindle-shaped lacunae at both end $\$$ of the tibiae and fibulae and at the distal end of the्w femur.

Hands and Wrists: Atrophy of the carpus and metacarpus, and of the epiphysis of the forearre (Fig. 7, opposite)

Thorax: A series of radiographs in January and February, 1954 (Figs $8 a, b, c$, opposite) followed the capricious development of pulmonary damage. The 


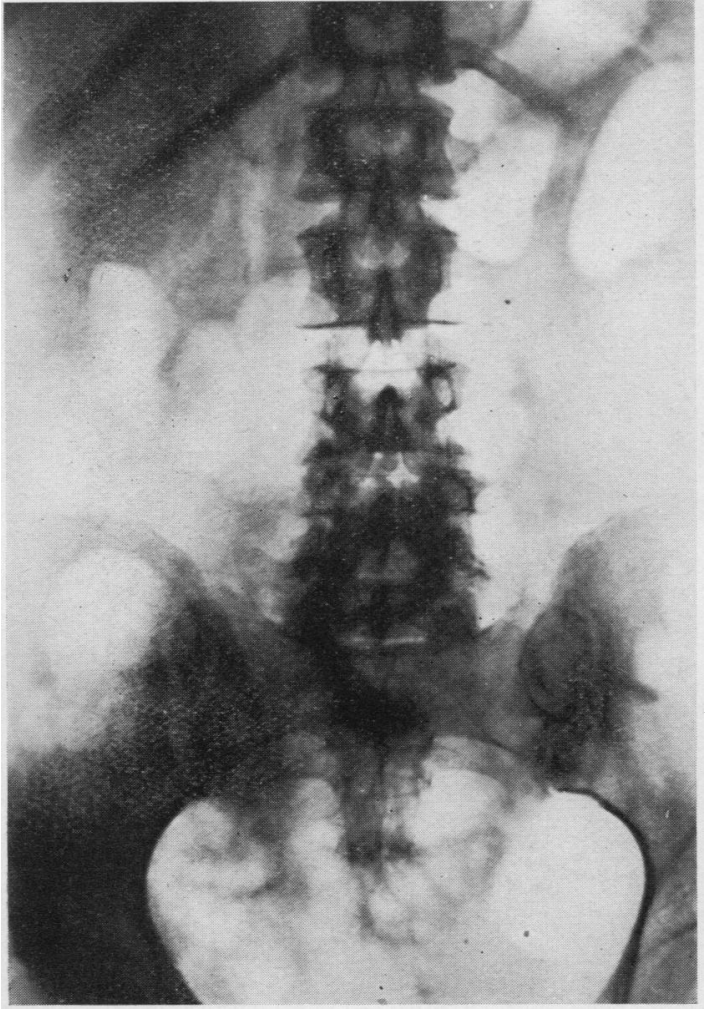

Fig. 6.-Spinal $x$ ray.

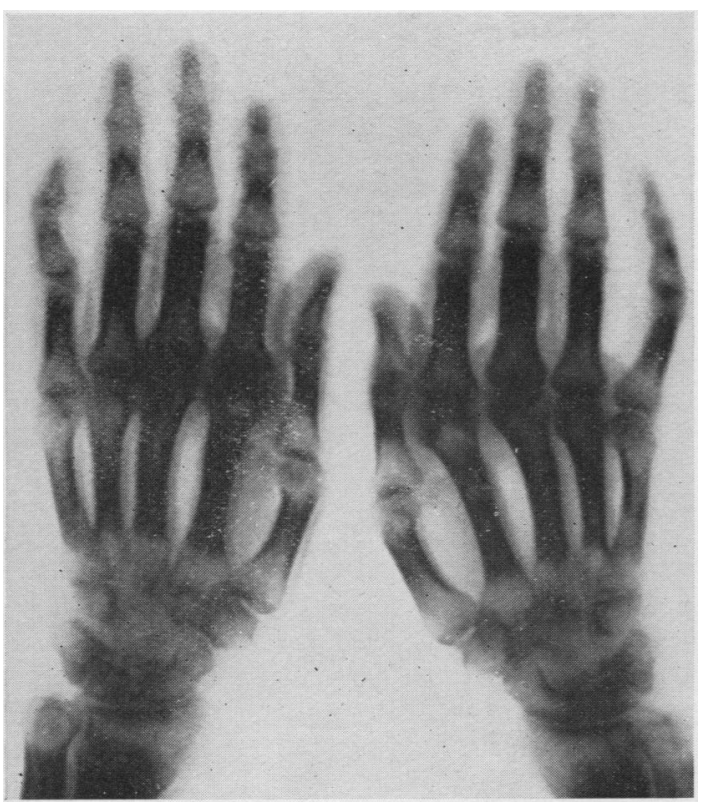

Fig. 7.- $X$ ray of hands and wrists.

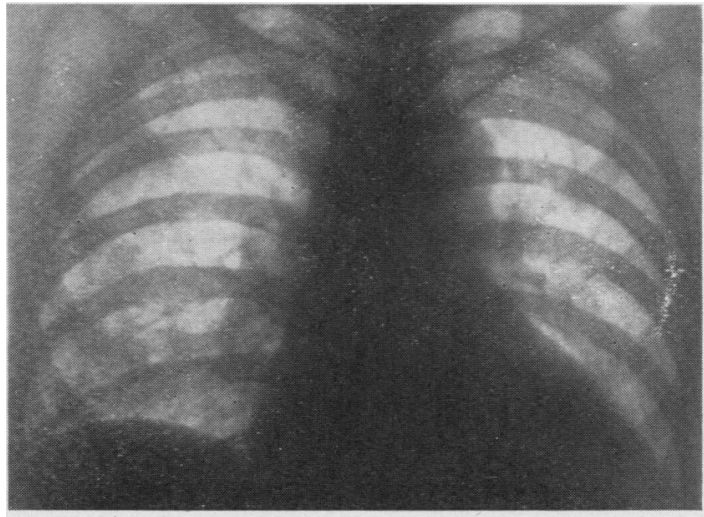

(a)

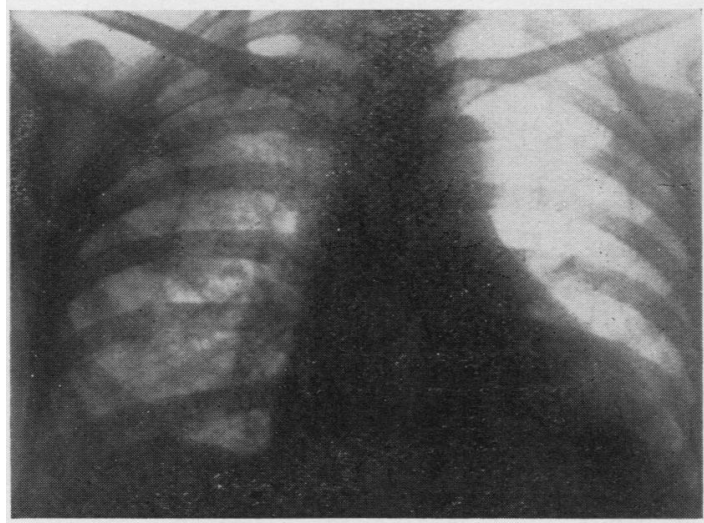

(b)

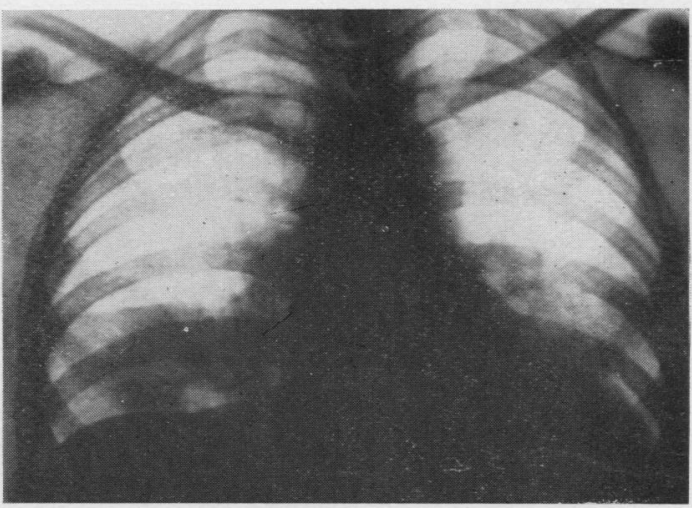

(c)

Fig. 8.-Thorax $x$ rays, showing development of pulmonary damage.
(a) 14.1.54
(b) 21.1.54
(c) 12.2 .54 
most important findings were always seen in the right field, where wide hypodiaphanic areas were present. Combined treatment with ACTH and antibiotics caused both pulmonary fields to clear up completely.

Clinical Course.-On admission to hospital, clinical signs of bilateral pulmonary involvement and high fever $\left(38-39^{\circ}\right.$ C.) were present. For this reason, and also because of collapse and poor general condition, penicillin 800,000 I.U. daily, streptomycin 1 g. daily, and cardiotonic and detoxicating treatment was given, but no improvement resulted.

On January 22, 1954, the patient vomited a yellowgreenish, bitter fluid; she showed anorexia, toxicosis, severe collapse, and oropharyngeal mucous inflammation, with diffuse moniliasis.

Pre-coma followed, with impaired and sterterous respiration, increased pulmonary involvement, weak rapid pulse, blood pressure $70-80 \mathrm{~mm}$. $\mathrm{Hg}$, and temperature $35 \cdot 6^{\circ} \mathrm{C}$.

Antibiotics were then withdrawn and the patient received only cardiotonic and detoxicating treatment.

After 2 days the heart block disappeared and the electrocardiographical tracing was practically normal, but the fever increased. Because of some migrating bronchopulmonary areas the patient was given terramycin (250 mg. daily) by drip phleboclysis, and ACTH intramuscularly. The temperature responded well within 3 days and was kept at normal levels.

Electrophoresis and bone-marrow examination now enabled a clear diagnosis to be made.

After ACTH and terramycin had been given both pulmonary fields cleared and a slight fall was seen in the erythrocyte sedimentation rate.

The high doses of ACTH were discontinued, and streptomycin administration was started, owing to a small effusion in the right pleura, which was found by an explorative puncture; a thick, yellowish, clear fluid was extracted and coagulated immediately; the Rivalta reaction was strongly positive.

The patient's general condition improved slightly, moniliasis disappeared, and feeding was again possible.

Twenty days after withdrawal of streptomycin, a new slight febrile attack occurred, with swelling, reddening, and pain in the finger joints.

Phenylbutazone ( $1 \mathrm{~g}$. daily for one week) caused improvement of these symptoms, but the patient died in May, 1954.

\section{Discussion}

Since clinical and radiological features of rheumatoid arthritis were present in our case, the diagnosis of rheumatoid arthritis secondary to myeloma could not be rejected. A few similar cases, considered by Chini (1955) to be cases of "myelomatous dysprotidaemic arthropathy", have already been reported in the literature.

In this instance our attention was first drawn to the rheumatoid arthritis and afterwards to the plasmacytoma. The following features supported the first diagnosis: (a) articular pattern, with an acute onset, followed $\frac{1}{3}$ by chronic progression. Through many exacer $\square$ bations, the joint involvement grew graduallyes. worse, and finally presented the classical picture of rheumatoid arthritis;

(b) constantly raised erythrocyte sedimentation rate

(c) striking dysprotidaemia with inversion of $\mathrm{A} / \mathrm{G} \overline{\mathrm{O}}$ ratio and increase of the $\beta$ globulin fraction;

(d) mild changes in the peripheral blood (mononuclear cells showed a degree of hyperbasophilia); conversely, plasma-cells were presentes in the bone marrow at the rate of 8 to 10 per cent., within the highest limits associated with rheumatoid arthritis;

(e) slight enlargement of the spleen;

( $f$ ) iridocyclitis accompanied by the so-calleff "dysprotidaemic fundus" picture;

(g) occasional Bence-Jones proteinuria, evident in $\vec{P}$ the terminal stages;

(h) moderate osteolytic lesions peculiar to rheuma toid arthritis;

(i) vascular changes (cutis marmorata) which may옹 be considered among the capillary phenomenasecondary to rheumatoid arthritis, and may ever $(S$ induce acropurpura (Anderson and Samuelson 1944).

To justify the second diagnosis, differentia criteria rather qualitative than quantitative are required:

(a) sedimentation rate abnormally raised;

(b) blood plasma disorders and related phenom extremely serious, the $\beta$ globulin peak being thes main feature in the electrophoretic curve;

(c) bone-marrow plasmocytosis, moderate in theo early stages, and later reaching a very higho level;

(d) lung involvement typical of myeloma;

(e) bone changes secondary to myeloma, though of limited extent:

$(f)$ Bence-Jones proteinuria;

(g) kidney impairment (shown by the high degree of albuminuria and blood nitrogen) suggestive of a renal disorder.

The type of arthropathy seen in this case is one that may be encountered in myeloma.

The diagnosis of atypical myeloma-like rheumatoid arthritis or of rheumatoid arthritis turned to myeloma would be hazardous on the basis of the laboratory findings, but the development of myeloma? on a biological background already greatly modified N by rheumatoid arthritis is a possibility. The relationship between the two diseases depends first on the association of rheumatoid arthritis with $\omega$ myeloma, and secondly on joint involvementर typical of early myeloma; the dysprotidaemic patho genesis of this disease was recently formulated by Chini, who suggested the description "dyspro-" tidaemic joint disease". 
Laboratory findings, and, in our case, radiological findings also, place rheumatoid arthritis close to myeloma, the differences being rather quantitative than qualitative. One might, therefore, expect a frequent clinical association of the two conditions, whereas, in fact, this is rare. However, the syndrome, having once been described, may be more frequently noted in the future, especially in cases of rheumatoid arthritis characterized by a severe and lethal progress in which serious plasma disorders rapidly affect the general health.

The practical interest of the case reported above lies in the differential diagnosis of some articular lesions commonly believed to be peculiar to rheumatoid arthritis. Many other "rheumatoid" joint alterations are known to occur in the so-called "pararheumatic" diseases (Friedman, Schwartz, Trubek, and Steinbrocker, 1953), in the Pierre-Marie syndrome, and in the so-called "dystrophic rheumatisms". The possibility of dysprotidaemic arthropathies of the rheumatic type has also to be kept in mind.

Furthermore, the present case offers an approach to the problem of inter-relations between protein disorders and the chronic articular ailments which may be directly correlated with them.

\section{Summary}

A case of polyarthritis is described, in which the clinical appearances had led to an early diagnosis of rheumatoid arthritis; subsequently, the clinical course and laboratory findings suggested plasmacytomatosis. A diagnosis of plasmacytoma accompanied by dysprotidaemic joint disease seems the more probable. This assumption is based on both the clinical course (atypical pulmonary involvement, severe and fatal progress) and the laboratory findings (tests for dysprotidaemia and bone-marrow function, muscular and synovial biopsies, and $x$-ray examinations).

\section{REFERENCES}

Andersson, B., and Samuelson, A. (1944). Acta med. scand., 117, 248. Apitz, K. (1940a). Klin. Wschr., 19, 1058.

- (1940b). Virchows Arch. path. Anat., 306, 631.

Bonsdorff, B. von (1934). KongrZbl., ges. inn. Med., 74, 85.
Cesa-Bianchi, D., and Poli, E. (1948). " "Relaz. 49॰ Congr. Soc. ital. Med. int., 1948." Pozzi, Roma.

Chini, V. (1955). Rev. Rhum., 22, In the press.

Dahlin, D. C. (1949). Amer. J. Pathol., 25, 105.

Delbarre, F. (1949). Rev. Rhum., 16, 375.

Friedman, H. H., Schwartz, S., Trubek, M., and Steinbrocker, O. (1953). Ann. intern. Med., 38, 732.

Galli, T., Bianchi, V., and Mannetti, C. (1949). Boll. Soc. ital. Biol. sper., $25,391$.

-_, Mannetti, C., and Bianchi, V. (1949). Minerva med. (Torino), parte sci., 40 (2), 13.

Lake,-1949 , and Rivano, R. (1949). Reumatismo, 1, 33.

Langh, F. (1937). Acta med. scand., 132, 440.

Lubarsch, O. (1929). Virchows Arch. path. Anat., 271, 867.

Magnus-Levy, A. (1932) Z. klin. Med. 121, 533.

Magnus-Levy, A. (1932). Z. Klin. Med.,

Meneghini, P., and Felini, F. (1954). Personal communication.

Poli, E. (1948). Omnia Med., 26, 551 .

(1949). Biol. latina., 2, 123.

Redaelli, C., and Gianni, A. (1949). Ibid., 2, 1.

Ronchetti, v. (1930). Osped. maggiore, 18, 1.

Snapper, I. (1938). "Maladies osseuses." Bohn, Haartem; Masson, Paris.

Stadler, L. (1939). Folia haemat. (Lpz.), 61, 353.

Stewart, A., and Weber, F. Parkes (1938). Quart. J. Med., n.s. 7, 211. Tarr, L., and Ferris, H. W. (1939). Arch. intern. Med., 64, 820.'

Vidari, E. (1941). Sperimentale, 95, 817.

- (1946). Haematologica, 29, 365.

Weissenbach, R. J., and Faulong, L. (1948). Rev. Rhum., 15, 189.

\section{Arthrite rhumatismale et plasmocytomatose}

\section{RÉSUMÉ}

On décrit un cas de polyarthrite chronique dont le tableau clinique fit d'abord penser à l'arthrite rhumatismale; plus tard l'évolution clinique et les résultats de laboratoire suggérèrent la plasmocytomatose. Le diagnostic de plasmocytoma accompagné de maladie articulaire dysprotidémique semble plus probable. Cette hypothèse se base aussi bien sur l'évolution clinique (implication pulmonaire atypique, évolution grave vers la mort) que sur les résultats de laboratoire (tests de dysprotidémie, ponction de la moelle osseuse, biopsies musculaires et synoviales et examens radiologiques).

\section{Artritis reumatoide $\mathbf{y}$ plasmocitomatosis}

\section{Sumario}

Se describe un caso de poliartritis crónica con un cuadro clínico que al principio llevó al diagnóstico de de artritis reumatoide pero que luego, en vista de la evolución clínica y de los resultados de laboratorio, hizo pensar en la plasmocitomatosis. El diagnóstico de plasmocitoma acompañado de enfermedad articular disprotidémica parece más probable. Esta hipótesis se basa tanto sobre la evolución clínica (compromiso pulmonar atípico, evolución grave hacia la muerte) como sobre los resultados de laboratorio (disprotidemia, punción de la médula ósea, biopsias musculares y sinoviales e investigación radiológica). 